\title{
Organization of methylamine utilization genes (mau) in 'Methylobacillus flagellatum' KT and analysis of mau mutants
}

\author{
Evgeny R. Gak, ${ }^{1}+$ Yuriy D. Tsygankov ${ }^{2}$ and Andrei Y. Chistoserdov ${ }^{3}$ \\ Author for correspondence: Andrei Y. Chistoserdov. Tel: +1516632 9233. Fax: +1 5166328820 . \\ e-mail : chistoserdov@ccmail.sunysb.edu
}

1 Environmental

Engineering Science, W. M.

Keck Laboratories 138-78,

California Institute of

Technology, Pasadena,

CA 91125, USA

2 Institute of Genetics and

Selection of Industrial

Microorganisms,

1 Dorozhniy pr. 1,

Moscow 114570, Russia

3 Marine Sciences Research Center, SUNY at Stony Brook, Stony Brook, NY 11794-5000, USA

\begin{abstract}
The organization of genes involved in utilization of methylamine (mau genes) was studied in the obligate methylotroph 'Methylobacillus flagellatum' KT. Nine open reading frames were identified as corresponding to the genes mauFBEDAGLMN. In addition, an open reading frame (orf-1) encoding a polypeptide with unknown function was identified upstream of the mau gene cluster. Subclones of the ' $M$. flagellatum' KT gene cluster were used for complementation of a series of chemically induced mau mutants of ' $M$. flagellatum' KT. Mutants in mauF, mauB, mauEID, mauA, mauG, mauL and mauM were identified. Two mutants (mau-18 and mau-19) were not complemented by the known mau genes. Since none of the chemically induced mutants studied had a defect in orf-1 or mauN, insertion mutants in these genes were constructed. Phenotypically the mutants fell into three groups. The mauF, mauB, mauEID, mauA, mauG, mauL and mauM mutants do not grow on methylamine as a source of carbon and lack methylamine dehydrogenase activity, but they synthesize both the large and the small subunit polypeptides albeit at different ratios. The mau-18 and mau-19 mutants do not grow on methylamine as a source of carbon, and lack both methylamine dehydrogenase activity and the methylamine dehydrogenase subunits. The orf-1 and mauN mutants grow on methylamine as a source of carbon and synthesize wild-type levels of methylamine dehydrogenase. It has been shown earlier that the product of the mauM gene is not required for synthesis of active methylamine dehydrogenase in Methylobacterium extorquens AM1 and Paracoccus denitrificans. However, MauM is required for synthesis of functional methylamine dehydrogenase in ' $M$. flagellatum'.
\end{abstract}

Keywords: 'Methylobacillus flagellatum', methylamine dehydrogenase, mau mutants, tryptophan tryptophylquinone

\section{INTRODUCTION}

Methylamine dehydrogenase (MADH) is a primary enzyme for the utilization of methylamine as a source of carbon in many methylotrophic bacteria. These bacteria include the facultative autotrophs Paracoccus

\footnotetext{
†Present address: Institute of Genetics and Selection of Industrial Micoorganisms, 1 Dorozhniy pr. 1, Moscow 114570, Russia.

Abbreviations: $\mathrm{MADH}$, methylamine dehydrogenase; TRQ, tryptophan tryptophylquinone.

The GenBank accession numbers for the mau gene cluster sequences from 'M. flagellatum' KT are L37426, L37427, L37428, L37429, L37433, L37434 and $\mathrm{L} 37435$.
}

denitrificans (Husain \& Davidson, 1987) and Thiobacillus versutus (Haywood et al., 1982), the facultative methylotroph Methylobacterium extorquens AM1 (Eady \& Large, 1968) belonging to the $\alpha$ subgroup of proteobacteria, the restricted facultative methylotroph Methylophilus methylotrophus W3A1 (Kenny \& McIntire, 1983) and the obligate methylotrophs 'Methylobacillus flagellatum' KT (Kiriukhin et al., 1990), Methylomonas sp. J. (Matsumoto et al., 1980) and Organism 4025 (Lawton $\&$ Anthony, 1985) belonging to the $\beta$ subgroup of proteobacteria, and Methylophaga spp. (Janvier et al., 1985), which have been recently assigned to the $\gamma$ subgroup of the proteobacteria. 
The MADH enzymes from diverse physiological groups of methylotrophs have been well studied and characterized biochemically (Eady \& Large, 1968; Haywood et al., 1982; Husain \& Davidson, 1987; Kenny \& McIntire, 1983; Kiriukhin et al., 1990; Lawton \& Anthony, 1985; Matsumoto et al., 1980) and have been shown to be similar. For all cases studied, $\mathrm{MADH}$ is a periplasmic protein consisting of two small and two large subunits. Each small subunit has a covalently bound prosthetic group called tryptophan tryptophylquinone (TTQ), synthesized from two tryptophan residues belonging to the small-subunit polypeptide chain (McIntire et al., 1991). The MADHs from restricted facultative methylotrophic bacteria belonging to the genus Methylophilus (Burton et al., 1983; Chandrasekar \& Klapper, 1986) use a $c$-type cytochrome as an electron acceptor, whereas MADHs from other methylotrophs use blue copper proteins - cupredoxins (Anthony \& Jones, 1987; Dinarieva \& Netrusov, 1989; Van Houwelingen et al., 1985; Husain \& Davidson, 1985; Lawson \& Anthony, 1985; Tobari, 1984; Tobari \& Harada, 1981). Organism 4025 and 'Methylobacillus flagellatum' KT can grow slowly on methylamine in a medium depleted of copper, and no cupredoxins can be detected (Dinarieva \& Netrusov, 1989; Lawton \& Anthony, 1985). An unknown cytochrome was suspected to function under such growth conditions, since the well-characterized cytochromes $c_{\mathrm{L}}$ and $c_{\mathrm{H}}$ in Organism 4025 do not accept electrons from MADH in vitro (Auton \& Anthony, 1989).

All or some of the genes responsible for MADH synthesis (mau genes) have been cloned from Methylobacterium extorquens AM1 (Chistoserdov et al., 1990, 1994a), P. denitrificans (Van Spanning et al., 1990; Chistoserdov et al., 1992; Van der Palen et al., 1995), T. versutus (Ubbink et al., 1991; Huitema et al., 1993), 'Methylobacillus flagellatum' KT (Gak et al., 1995) and Methylophilus methylotrophus W3A1 (Chistoserdov et al., 1994b). The mau gene clusters from T. versutus, $P$. denitrificans and $M$. extorquens AM1 contain genes for amicyanin $(\operatorname{manC})$ and a polypeptide with unknown function (mauJ) between mauA (encoding the MADH small-subunit polypeptide) and mauG (encoding a putative peroxidase) (Chistoserdov et al., 1994a; $V$ an Spanning et al., 1990; Ubbink et al., 1991). In the M. methylotrophus W3A1-NS and 'M. flagellatum' KT chromosome mauC and mauJ are missing, and mauG immediately follows manA (Chistoserdov et al., 1994b; (Gak et al., 1995). A distinctive feature of the mau gene cluster from ' $M$. flagellatum' $\mathrm{KT}$ is that the cluster is followed by the gene for azurin (Gak et al., 1995). The present article addresses the question of the organization of the mau gene cluster from ' $M$. flagellatum' KT and describes the analysis of a set of chemically induced and insertional mau mutants.

\section{METHODS}

Bacterial strains and plasmids and growth conditions. The bacterial strains and plasmids used in this work are shown in Table 1. All Escherichia coli strains were grown in
Luria-Bertani medium in the presence of appropriate antibiotics as described by Maniatis et al. (1982), except that the concentration of chloramphenicol for pAYC63 derivatives was $0.01 \mathrm{mg} \mathrm{ml}^{-1}$. IPTG and X-Gal were added at $0.04 \mathrm{mg} \mathrm{m}^{-1}$. The 'Methylobacillus flagellatum' $\mathrm{KT}$ strains were grown in the minimal medium described by Fulton $e t$ al. (1984), except that it was used in double strength and its $\mathrm{pH}$ was adjusted to $7 \cdot 2-7 \cdot 3$ with sodium hydroxide. The nitrogenfree medium used was the minimal medium with sodium sulfate $\left(0 \cdot 2 \mathrm{~g} \mathrm{l}^{-1}\right)$ substituted for ammonium sulfate and ammonium molybdate omitted. The concentrations of tetracycline ( $\mathrm{Tc}$ ), ampicillin (Ap), rifamycin, chloramphenicol $(\mathrm{Cm})$ and kanamycin $(\mathrm{Km})$ for growing the $M$. methylotrophus KT strains were $0.001,1,0.1,0.15$ and $0 \cdot 15 \mathrm{mg} \mathrm{ml}^{-1}$ respectively. Methanol $(2 \%, \mathrm{v} / \mathrm{v}$, unless indicated differently in the text) and methylamine hydrochloride $(0.4 \%, \mathrm{w} / \mathrm{v})$ were used as carbon sources. Ethylamine, ethanolamine, propylamine, dimethylamine and trimethylamine hydrochlorides in $0.2 \%$ concentration were assessed as nitrogen sources.

DNA-DNA hybridizations. DNA-DNA hybridizations were carried out in dried agarose gels in accordance with the procedure described by Meinkoth \& Wahl (1984). The temperature of hybridizations $(6 \times \mathrm{SSC}, 0 \cdot 1 \%$ SDS $)$ and washes $\left(0.5 \times \mathrm{SSC}, 0.1 \%\right.$ SDS) was $68^{\circ} \mathrm{C}$. $1 \times \mathrm{SSC}$ is $0.15 \mathrm{M}$ sodium chloride and 0.015 $\mathrm{M}$ sodium citrate solution, $\mathrm{pH} 7 \cdot 0$.

DNA manipulations. Plasmid isolation, E. coli strain transformation, preparative isolation of the DNA fragments from agarose gels, restriction endonuclease digestion, ligation, and blunting of ends with Klenow fragment or T4 DNA polymerase were carried out as described by Maniatis et al. (1982). Random primer labelling of DNA fragments was done as suggested by the manufacturer (Boehringer Mannheim). Chromosomal DNA of the ' $M$. flagellatum' KT strains was isolated in accordance with the procedure of Marmur (1961).

DNA sequencing. DNA sequencing was performed by the dideoxy chain-termination method on both strands in the UCLA DNA Sequenator Core Facility on an Applied Biosystems sequenator. Plasmid pAYC63 $\left(\mathrm{Cm}^{R}\right.$; Chistoserdov et al., 1992) was used as a vector for subcloning and sequencing in addition to pUC19 $\left(\mathrm{Ap}^{\mathrm{R}}\right)$.

Matings. Bi- and triparental matings were done as described by Fulton $e$ t al. (1984). pRK2013 was used as a helper plasmid in triparental matings.

Isolation of chemically induced mutants of ' $M$. flagellatum' KT. The 1-methyl-3-nitro-1-nitrosoguanidine mutagenesis procedure used in this research was as described by Miller (1972) with modifications for ' $M$. flagellatum' KT (Kletsova et al., 1988). Carbenicillin $\left(1 \mathrm{mg} \mathrm{ml}^{-1}\right)$ and $\mathrm{D}$-cycloserine $\left(0.3 \mathrm{mg} \mathrm{ml}^{-1}\right)$ were used for enrichment of mutants as described by Miller (1972), except that incubation time with antibiotics was increased to $24 \mathrm{~h}$.

Construction of insertional mau strains. Insertion mau mutants were constructed by homologous recombination as described previously (Ruvkun \& Ausubel, 1981). The $\mathrm{Km}^{\mathrm{R}}$ cassette from pUC4K was used as a selective inactivating marker and plasmids pAYC61 (Chistoserdov et al., 1994a) and pSUP2021 (Simon et al., 1983) were used as suicide vectors.

MADH assay. ' $M$. flagellatum' KT cells were broken by the following osmotic shock procedure. Cells from $50 \mathrm{ml}$ cultures were collected by centrifugation, suspended in $1.5 \mathrm{ml}$ of $25 \%$ $(\mathrm{w} / \mathrm{v})$ sucrose solution in $50 \mathrm{mM}$ Tris $/ \mathrm{HCl}$ buffer $\mathrm{pH} 7 \cdot 5$, and 
Table 1. Bacterial strains and plasmids used in this study

\begin{tabular}{|c|c|c|}
\hline Strain or plasmid & Description & Source or reference ${ }^{*}$ \\
\hline \multicolumn{3}{|l|}{ E. coli } \\
\hline $\mathrm{DH} 5 \alpha$ & $\begin{array}{l}\mathrm{F}^{-} \phi 80 \mathrm{~d}(\text { lac } \Delta Z) M 15 \text { hsdR17 supE44 } \\
\text { thi-1 gyrA96 endA1 recA1 relA? } \\
\Delta(\text { lacZYA-argF }) \text { U169 }\end{array}$ & New England Bio-Labs \\
\hline S17-1 & 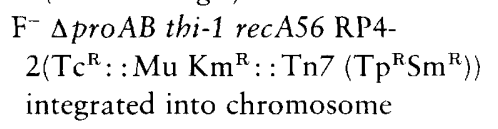 & Simon et al. (1983) \\
\hline \multicolumn{3}{|c|}{ 'M. flagellatum' KT } \\
\hline KT-rif & Wild-type, rif-1 & Govorukhina et al. (1987) \\
\hline MFK-51 & met-1 rif-2 & Kletsova et al. (1988) \\
\hline KT-2.1 & mauA1 met-1 rif-2 & \\
\hline KT-2.9 & mau-19 met-1 rif-2 & \\
\hline $\mathrm{KT}-2.18$ & mau-18 met-1 rif- 2 & \\
\hline $\mathrm{KT}-3$ & mauB1 met-1 rif-2 & \\
\hline $\mathrm{KT}-5$ & manG1 met-1 rif- 2 & \\
\hline KT-8 & mauF1 met-1 rif-2 & \\
\hline KT-10 & mau-10 met-1 rif-2 & \\
\hline KT-13 & mauM1 met-1 rif-2 & \\
\hline $\mathrm{KT}-24$ & mau-24 met-1 rif- 2 & \\
\hline KT-25 & mauG2 met-1 rif- 2 & \\
\hline $\mathrm{KT}-26$ & mau -26 met -1 rif -2 & \\
\hline KT-32 & mau-32 met -1 rif- 2 & \\
\hline $\mathrm{KT}-56$ & mauL1 met-1 rif-2 & \\
\hline KT-61 & mauL2 met-1 rif- 2 & \\
\hline KT-78 & $\operatorname{man} G 3$ rif-1 & \\
\hline KT-79 & mauB2 met-1 rif-2 & \\
\hline KT-85 & mauL3 met-1 rif- 2 & \\
\hline KT-86 & mauF2 met-1 rif-2 & \\
\hline $80-2$ & $\operatorname{manN1}:: \mathrm{Km}^{\mathrm{R}}$ rif-1 & \\
\hline $305 c-1$ & $a z u:: \mathrm{Km}^{\mathrm{R}}$ rif -1 & \\
\hline $306 a-1$ & orf $-1:: \mathrm{Km}^{\mathrm{R}}$ rif-1 & \\
\hline \multicolumn{3}{|l|}{ Plasmids } \\
\hline pRK310 & $\mathrm{Tc}^{\mathrm{R}} l a c \mathrm{Z}^{\prime} m o b^{+} \mathrm{IncP}$ & Ditta et al. (1985) \\
\hline pRK2013 & $\mathrm{Km}^{\mathrm{R}} \operatorname{tra}^{+}$IncColE1 & Ditta et al. $(1985)$ \\
\hline pUC19 & $\mathrm{Ap}^{\mathrm{R}}$ lac $\mathrm{Z}^{\prime}$ & New England Bio-Labs \\
\hline pAYC61 & $\mathrm{Ap}^{\mathrm{R}} \mathrm{Tc}^{\mathrm{R}} m o b^{+}$IncColE1 & Chistoserdov et al. (1994a) \\
\hline pAYC63 & $\mathrm{Cm}^{\mathrm{R}}$ lac $\mathrm{Z}^{\prime}$ & Chistoserdov et al. (1992) \\
\hline pSUP202 & $\mathrm{Ap}^{\mathrm{R}} \mathrm{Cm}^{\mathrm{R}} \mathrm{Tc}^{\mathrm{R}} m o b^{+}$IncColE1 & Simon et al. (1983) \\
\hline pUC4K & $\mathrm{Ap}^{\mathrm{R}} \mathrm{Km}^{\mathrm{R}}$ & Pharmacia \\
\hline pGak1 & $\mathrm{Ap}^{\mathrm{R}} \operatorname{mauD^{\prime }} A G L M N$ azu & \\
\hline pGak2 & $\mathrm{Tc}^{\mathrm{R}}$ orf -1 mauFBEDAGLM ${ }^{\prime} m o b^{+}$ & \\
\hline pGak4 & $\mathrm{Tc}^{\mathrm{R}} \operatorname{mauD^{\prime }} A G L M N$ azu $m o b^{+}$ & \\
\hline pGak6 & $\mathrm{Tc}^{\mathrm{R}} m a u D^{\prime} A G^{\prime} m o b^{+}$ & \\
\hline pGak7 & $\mathrm{Tc}^{\mathrm{R}} \operatorname{mauD^{\prime }} A G L^{\prime} N^{\prime} a z u m o b^{+}$ & \\
\hline pGak11 & $\mathrm{Tc}^{\mathrm{R}}$ orf -1 mauFB $m o b^{+}$ & \\
\hline pGak60 & $\mathrm{Tc}^{\mathrm{R}} \operatorname{mau} M^{\prime} \mathrm{N} a z u^{\prime} m o b^{+}$ & \\
\hline pGakS & $\mathrm{Tc}^{\mathrm{R}} m a u B^{\prime} E D A G^{\prime} m o b^{+}$ & \\
\hline pGakR & $\mathrm{Tc}^{\mathrm{R}} m a u B^{\prime} E m o b^{+}$ & \\
\hline
\end{tabular}

* Where no source or reference is given, the strain or plasmid was derived in this study.

washed twice using $1 \mathrm{ml}$ of the same buffer. A $0.48 \mathrm{ml}$ sample of the cell suspension was withdrawn and was supplemented with $0.5 \mathrm{ml}$ lysozyme solution in the same sucrose buffer $\left(0.2 \mathrm{mg} \mathrm{ml}^{-1}\right)$ and $0.02 \mathrm{ml} 0.5 \mathrm{M}$ EDTA to form protoplasts.
After incubation at $37^{\circ} \mathrm{C}$ for $15 \mathrm{~min} 0.2 \mathrm{ml}$ protoplast suspension was diluted with $0.8 \mathrm{ml}$ cold distilled water, causing lysis. Cell debris was pelleted by centrifugation for $30 \mathrm{~min}$ in a refrigerated Eppendorf centrifuge (14000 r.p.m.). 
MADH in periplasmic extracts was measured spectrophotometrically in accordance with Eady \& Large (1968). Protein concentrations and the precise concentration of lysozyme in the lysozyme solutions were measured as described by Whitaker \& Granum (1980). The lysozyme concentration was subtracted to obtain concentrations of cellular proteins in extracts.

Computer analysis of DNA sequences. Computer analysis was carried out by using PCGENE (Genofit) and GCG (University of W'isconsin Genetic Computer Group).

Electrophoresis of proteins. The Laemmli system was used for SDS-PAGE (Laemmli, 1970). Separations were done in $13 \%$ $(\mathrm{w} / \mathrm{v})$ or $15 \%(\mathrm{w} / \mathrm{v})$ gels. Protein standards for SDS-PAGE were from Bio-Rad.

Transfer of proteins onto membranes. Proteins were transferred onto nitrocellulose membranes for immunoblot experiments and quinone-specific staining using the standard protocol provided by the manufacturer of the 'Trans-blot cell' apparatus (Bio-Rad), using a $4 \mathrm{~h}$ transfer time.

Immunoblot experiments. The 'i Assay Kit' (Bio-Rad) was used to detect the MADH large-subunit polypeptide and the 'Amplified Alkaline Phosphatase i Kit' (Bio-Rad) was used to detect the MADH small-subunit polypeptide. The kits were used in accordance with the manufacturer's recommendations.

Quinone-specific staining. This was done as described by Paz et al. (1991).

\section{RESULTS}

\section{Organization of the mau gene cluster}

Cloning of the mau gene cluster from 'Methylobacillus flagellatum' KT was reported in our earlier work (Gak et al., 1995). This mau gene cluster was cloned as two overlapping fragments of chromosomal DNA : an $8.5 \mathrm{~kb}$ Pst I fragment and a $4.5 \mathrm{~kb}$ HindIII fragment (Fig. 1). Since complete or partial nucleotide sequences of several mau gene clusters were available (Chistoserdov et al., $1994 a, b)$, partial sequencing was used to identify open reading frames sharing substantial similarity to known mau genes and thus to define the mau gene cluster organization. The sequencing strategy was based on the assumption that the mau gene cluster from ' $M$. flagellatum' KT might resemble that of Methylophilus methylotrophus W3A1. Nine open reading frames (mauFBEDAGLMN) transcribed in the same direction were identified (Fig. 1) that show substantial similarity (33 to $95 \%$ identity) to their counterparts from $M$. methylotrophus W3A1. All mau genes have strong ribosome-binding sites (at least four bases complementary to the $3^{\prime}$ end sequence of $16 \mathrm{~S}$ rRNA), with the strongest, AGGAGGAAA, in front of mauB.

Areas adjacent to the mau gene cluster were also sequenced. One open reading frame was found (orf -1 in Fig. 1) which is transcribed in the same direction as the mau genes and is located $450 \mathrm{bp}$ upstream of mauF. It is predicted to encode a putative periplasmic polypeptide of 200 amino acids (21706 Da). A search of the GenBank database did not reveal any gene or protein with considerable similarity to orf- 1 or its corresponding polypeptide.
Several potential hairpin structures were identified in the sequenced region (Fig. 1). A hairpin structure with predicted energies of production of $-20.6 \mathrm{kcal} \mathrm{mol}^{-1}$ $\left(-86 \cdot 1 \mathrm{~kJ} \mathrm{~mol}^{-1}\right)$ is located between $\operatorname{manN}$ and $a z u$. This hairpin structure closely resembles a $\rho$-independent terminator of $E$. coli. Four possible hairpin structures are located between orf -1 and mauF. They all have relatively low free energies of production $(-9.4$ to $-11.8 \mathrm{kcal} \mathrm{mol}^{-1}$; -39.3 to $-49.3 \mathrm{~kJ} \mathrm{~mol}^{-1}$ ) and they do not resemble $\rho$-independent terminators of $E$. coli.

\section{Generation of chemically induced mau mutants}

In order to further analyse the mau system, a number of $\mathrm{Mau}^{-}$mutants of ' $M$. flagellatum' $\mathrm{KT}$ were generated using $N$-methyl- $N$ '-nitro- $N$-nitrosoguanidine mutagenesis (Kletsova et al., 1988). All attempts to generate mau mutants by chemical treatment were unsuccessful until carbenicillin and D-cycloserine in combination were used for enrichment. The frequency of occurrence of mau mutants after such the enrichment was $5 \times 10^{-3}$. Of 62 mutants initially isolated as growing on methanol but not on methylamine, only 18 were found to inherit the $\mathrm{Mau}^{-}$phenotype stably, with reversion frequencies less than $10^{-8}$, and they were used for further work (Table 1).

\section{Complementation analysis of mau mutants}

To identify mutants containing lesions in the known mau genes, the $8.5 \mathrm{~kb}$ Pst I and $4.5 \mathrm{~kb}$ HindIII fragments were subcloned into the broad-host-range vector pRK310 such that the mau genes were transcribed from the lac promoter. The plasmids used were designed to distinguish between mutants in each mau gene, and included pGak2 (orf-1 mauFBEDAGLM') containing the entire $8.5 \mathrm{~kb}$ Pst I fragment, pGak4 (mauD'AGLMN $a z u)$ containing the entire $4.5 \mathrm{~kb} H$ indIII fragment, pGak6 (mauD $\left.D^{\prime} A G^{\prime}\right)$ containing a HindIII-NsiI subfragment of pGak1, pGak7 (mauD'AGL'N'azu), the result of an EcoRV-Pml I deletion in pGak4, pGak11 (orf-1 mauFB') containing a PstI-BamHI subfragment of pGak2, pGak60 (mauM'N $\left.a z u^{\prime}\right)$ containing a PstI-HincII subfragment of pGak1, pGakS ( $m a u B^{\prime} E D A G^{\prime}$ ) containing a HinclI-SmaI subfragment of the $8.5 \mathrm{~kb}$ Pst I fragment, and pGakR (mauB'E) containing a Hincll-EcoRV subfragment of the $8.5 \mathrm{~kb}$ fragment (Fig. 1). These plasmids were introduced into each mutant in triparental matings with selection for $\mathrm{Tc}^{\mathrm{R}}$. One hundred transconjugants from each mating were checked for the ability to grow on methanol. In all the cases, tansconjugants showed a uniform phenotype (all $\mathrm{Mau}^{-}$or all $\mathrm{Mau}^{+}$). The colonies of transconjugants selected after the transfer of pGakR into KT-10, KT-24, KT-26 and KT-32 were tiny and we were not able to restreak them. Therefore, we cannot identify precisely the nature of the lesion in these mutants; they are either mauE or mauD. The plasmids used would also not distinguish between mutants in orf-1 and mauE, but in this case orf-1 mutants were shown to be $\mathrm{Mau}^{+}$(see below). 
(a)

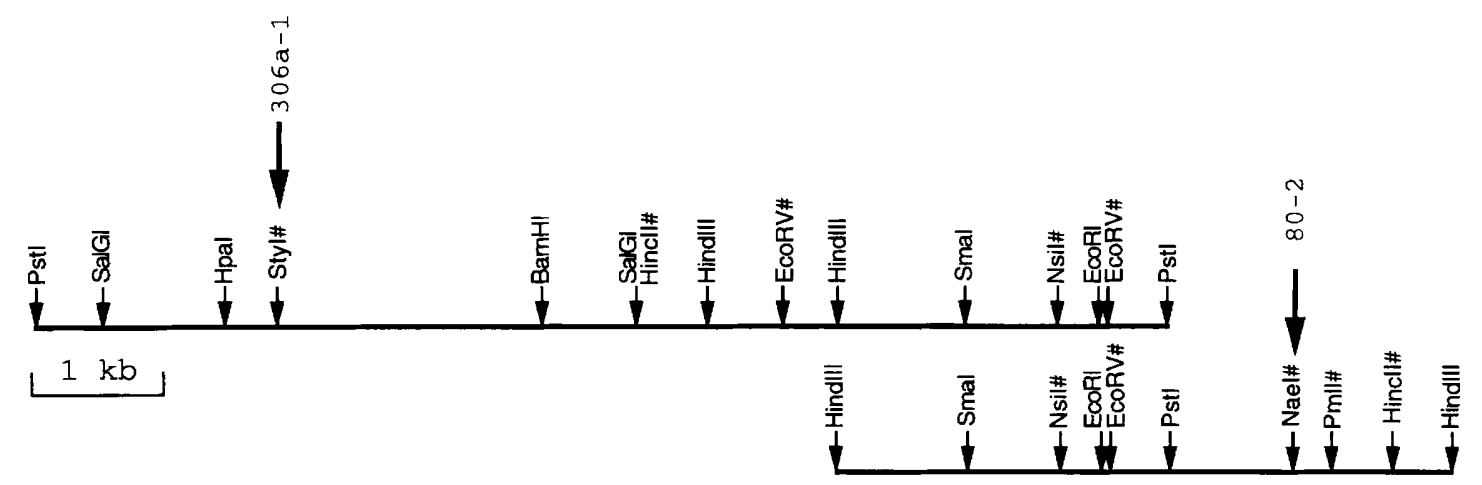

(c)

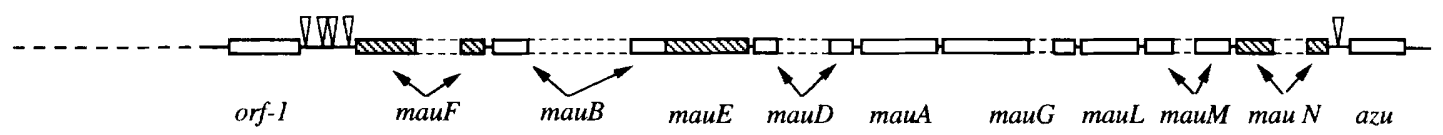

(d)

pGak2

pGak4

pGak6

pGak7

pGak11

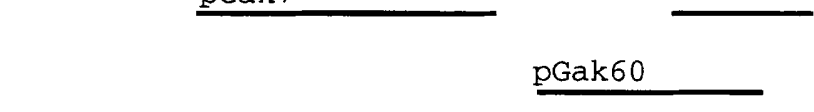

pGaks

pGakR

Fig. 1. Physical and genetic maps of the mau gene cluster from ' $M$. flagellatum' $K T$. (a) Restriction map of the $8.5 \mathrm{~kb} P s t \mathrm{f}$ fragment in pGak2. (b) Restriction map of the $4.5 \mathrm{~kb}$ Hindlll fragment in pGak1. Restriction sites with hash signs (\#) are not unique on these fragments; not all sites are shown. Arrows above the maps indicate sites of the Km-resistance gene insertions and corresponding mutant names. (c) Genetic map of the mau gene cluster. Sites of predicted hairpin structures are denoted by triangles; open boxes denote open reading frames encoding putative periplasmic polypeptides; hatched boxes denote open reading frames encoding putative membrane-bound polypeptides. Boxes whose edges are dashed represent unsequenced portions of mau genes. The single dashed line represents unsequenced areas or areas sequenced from one strand. All genes shown are transcribed left to right except azu, which is transcribed right to left. (d) The inserts in the plasmids (pGak2, pGak4, pGak6, pGak7, pGak11, pGak60, pGakS, pGakR) used for complementation analysis.

Complementation analysis allowed us to identify the nature of mau mutations in all of the mutants (Table 2) except for two, mau-18 and mau-19. These two mutants were not complemented by the known mau genes, and apparently they have impairments in unknown genes. No $\operatorname{mauN}$ or orf-1 mutants were found. Of the 16 mutants identified one each was defective in $m a u A$ and mauM, two each in $\operatorname{mauB}$ and $m a u F$, three each in mau $G$ and mauL, and four in mauD/mauE.

\section{Generation of insertion mutations in the mauN gene and orf-1}

In order to obtain information about the function of mauN and orf-1, insertion mutants were generated in these two genes by homologous recombination between the chromosome and plasmids containing insertions in the genes. The $\mathrm{Km}^{\mathrm{R}}$ cassette from pUC4K was inserted in the genes at the sites noted in Fig. 1. The insertions of the $\mathrm{Km}^{\mathrm{R}}$ cassette in which the $a p h$ gene is transcribed in the same direction as the inactivated gene (mauN or orf1) were selected for further studies. The constructs with mutagenized genes were recloned into the suicide vector pAYC61 (orf-1) or pSUP2021 (mauN) and introduced into the ' $M$. flagellatum' chromosome by conjugation and selection on plates with methanol and $\mathrm{Km}$. Approximately $90-95 \%$ of the transconjugants analysed were $\mathrm{Km}^{\mathrm{R}} \mathrm{Ap}^{\mathrm{S}} \mathrm{Tc}^{\mathrm{S}}$ (or $\mathrm{Km}^{\mathrm{R}} \mathrm{Ap}^{\mathrm{S}} \mathrm{Cm}^{\mathrm{S}}$ for pSUP202), the phenotypes indicative of double crossover recombination.

Chromosomal DNAs of these mutants were hybridized with pUC4K and the corresponding DNA fragment 
Table 2. Characteristics of chemically induced $\mathrm{Mau}^{-}$mutants of ' $M$. flagellatum' $\mathrm{KT}$

None of the $\mathrm{Mau}^{-}$mutants had detectable MADH activity. The MADH activity of the wild-type was $50 \mathrm{nmol} \mathrm{min}^{-1}\left(\mathrm{mg} \mathrm{protein}^{-1}\right.$.

\begin{tabular}{|c|c|c|c|c|c|c|c|c|c|c|c|c|}
\hline \multirow{3}{*}{$\begin{array}{l}\text { Mutant (initial } \\
\text { mutation } \\
\text { designation) }\end{array}$} & \multicolumn{8}{|c|}{ Complementation by pGak plasmids* } & \multirow{2}{*}{\multicolumn{2}{|c|}{$\begin{array}{c}\text { Presence of } \\
\text { subunits } \dagger\end{array}$}} & \multirow{3}{*}{$\begin{array}{l}\text { Quinone } \\
\text { staining } †\end{array}$} & \multirow{3}{*}{$\begin{array}{c}\text { Nature } \\
\text { of mutation }\end{array}$} \\
\hline & \multirow[t]{2}{*}{ pGak2 } & \multirow[t]{2}{*}{ pGak4 } & \multirow[t]{2}{*}{ pGak6 } & \multirow[t]{2}{*}{ pGak7 } & \multirow{2}{*}{\multicolumn{2}{|c|}{ pGak11 pGak60 }} & \multirow[t]{2}{*}{ pGakS } & \multirow{2}{*}{ pGakR } & & & & \\
\hline & & & & & & & & & Large & Small & & \\
\hline Wild-type & & & & & & & & & ++ & ++ & ++ & \\
\hline $\mathrm{KT}-2.1(\operatorname{man}-11)$ & + & + & + & + & & & & & ++ & + & ++ & $\operatorname{man} A 1$ \\
\hline KT-2.9 (mau-19) & - & - & - & - & - & & & & - & - & - & Unknown \\
\hline $\mathrm{KT}-2.18(\operatorname{man}-18)$ & - & - & - & - & - & & & & - & - & - & Unknown \\
\hline $\mathrm{KT}-3(\operatorname{mau}-3)$ & + & - & - & - & - & & - & - & ++ & + & ++ & mauB1 \\
\hline $\mathrm{KT}-5(\operatorname{mau}-5)$ & + & + & - & + & & & & & ++ & ++ & ++ & $\operatorname{manG1}$ \\
\hline KT-8 (mau- 8$)$ & + & - & - & - & + & & & & ++ & ++ & ++ & $\operatorname{mauF1}$ \\
\hline $\mathrm{KT}-10(\operatorname{mau}-10)$ & + & - & - & - & - & & + & & ++ & + & ++ & $\operatorname{mauD}$ or $\operatorname{mauE}$ \\
\hline $\mathrm{KT}-13(\operatorname{mau}-13)$ & - & + & - & - & & - & & & ++ & ++ & ++ & $\operatorname{manM1}$ \\
\hline $\mathrm{KT}-24(\operatorname{mau}-24)$ & + & - & - & - & - & & + & & ++ & + & ++ & $\operatorname{man} D$ or $\operatorname{man} E$ \\
\hline $\mathrm{KT}-25(\mathrm{mau}-25)$ & + & + & - & + & & & & & ++ & ++ & ++ & $\operatorname{man} G 2$ \\
\hline $\mathrm{KT}-26(m a u-26)$ & + & - & - & - & - & & + & & ++ & + & ++ & $\operatorname{mau} D$ or $\operatorname{mauE}$ \\
\hline $\mathrm{KT}-32(\operatorname{mau}-32)$ & + & - & - & - & - & & + & & ++ & + & ++ & $\operatorname{mauD}$ or $\operatorname{manE}$ \\
\hline KT-56 (mau-56) & + & + & - & - & & & & & ++ & ++ & ++ & mauL1 \\
\hline KT-61 (mau-61) & + & + & - & - & & & & & ++ & ++ & ++ & $\operatorname{mauL2}$ \\
\hline KT-78 (mau-78) & + & + & - & + & & & & & ++ & ++ & ++ & $\operatorname{man} G 3$ \\
\hline KT-79 (mau-79) & + & - & - & - & - & & - & - & ++ & ++ & ++ & $\operatorname{manB2}$ \\
\hline KT-85 (mau-85) & + & + & - & - & & & & & ++ & ++ & ++ & $\operatorname{manL3}$ \\
\hline $\mathrm{KT}-86($ mau-85) & + & - & - & - & + & & & & + & + & ++ & mauF2 \\
\hline
\end{tabular}

$*+$, Complementation; - , absence of complementation.

$t++$, Property is the same as wild-type; + , considerable decrease compared to the wild-type; - absence of property.

which was used in generating the mutant. In all cases a $1.4 \mathrm{~kb}$ increase in the mutagenized fragments was observed, confirming the presence of only the $\mathrm{Km}^{\mathrm{R}}$ cassette (data not shown).

All of the insertion mutants were able to grow on methylamine. This fact may explain why no chemically induced mutants were identified for these two genes. Mutants 306a-1 (orf-1) and 80-2 (mauN) were indistinguishable in their properties from the wild-type strain and therefore they were not used for further studies.

\section{Phenotypic analysis of mau mutants}

'M. flagellatum' KT can grow only on methylamine or methanol as sources of carbon (Govorukhina et al., 1987). To determine which amines this bacterium can utilize as sources of nitrogen, growth of the wild-type ' $M$. flagellatum' KT was assessed in nitrogen-free medium containing methanol as a source of carbon to which each of the amines listed in Methods were added. Ethylamine, ethanolamine, dimethylamine and n-propylamine, but not trimethylamine, served as nitrogen sources for ' $M$. flagellatum' KT.

The chemically induced mau mutants were checked for their ability to utilize the amines listed above as sources of carbon and/or nitrogen. All mutants were able to use methylamine, ethylamine, ethanolamine, dimethylamine and n-propylamine as sources of nitrogen, but not trimethylamine. The growth rates of the mutants with the amines as sources of nitrogen were essentially identical to that of the wild-type.

To further characterize the mutant phenotypes, the following properties were studied: the presence of MADH activity; the presence of large and small subunits in immunoblot experiments; and the presence of quinone in the small-subunit polypeptide as assessed using a quinone-specific stain.

It is known for several methylotrophic bacteria that the presence of methanol in the growth medium substantially represses MADH activity even if the natural inducer of MADH, methylamine, is also present. The concentration of methanol $(2 \%)$ normally used for growing ' $M$. flagellatum' KT totally represses MADH synthesis in the presence of $0.4 \%$ methylamine. At $0.5 \%$ methanol in the presence of $0.4 \%$ methylamine, partial derepression of MADH can be achieved (Table 2), and these concentrations of growth substrate and the inducer were used to measure MADH activities in the mutants and wild-type.

All $\mathrm{Mau}^{-}$mutants showed no detectable MADH ac- 
tivity, while the $\mathrm{Mau}^{+}$insertion strains had activities virtually identical to that of the wild-type strain (data not shown). To determine whether the large- and smallsubunit polypeptides are synthesized in the $\mathrm{Mau}^{-}$ mutants, immunoblot experiments with antibodies specific for the MADH large or small subunits were performed. The large- and small-subunit polypeptides were detected in extracts of all strains except mau-18 and mau-19, which lacked both subunits. The ratio between the large and small subunits differed from strain to strain. In the mauA (KT2.1) and mauE/D (KT10, KT24, KT26, KT32) strains the amounts of the small-subunit polypeptide were decreased relative to the amounts of the large subunit polypeptide. In one mutant (KT86) both the large and small subunit polypeptides were present at levels lower than that of the wild-type strain, but the ratio between the large and small polypeptides for KT86 was the same as for the wild-type. A redoxcycling staining procedure has been developed by $\mathrm{Paz}$ et al. (1991) for specific staining of quinoproteins; it allows the specific staining of the MADH small-subunit polypeptide after transfer to a membrane from a denaturing polyacrylamide gel. A set of polypeptides was stained by this procedure in extracts from all strains, including a polypeptide with molecular mass around $14 \mathrm{kDa}$, which corresponds to the MADH small subunit. The only two exceptions were mau-18 and mau-19, which lacked the $14 \mathrm{kDa}$ polypeptide.

\section{DISCUSSION}

The organization of the mau gene cluster in 'Methylobacillus flagellatum' $\mathrm{KT}$ is very similar to that in Methylophilus methylotrophus W3A1-NS. Not only is the gene order the same, but the partial sequences determined for each ' $M$. flagellatum' KT mau gene also shows high similarity to the analogous $M$. methylotrophus W3A1-NS mau genes. Mutants of ' $M$. flagellatum' KT that were defective in each of the mau genes also showed phenotypes consistent with the proposed function of each gene and resembling phenotypes described for analogous mau mutants of other micro-organisms (Chistoserdov et al., 1994a). Thus, mauN mutants of both ' $M$. flagellatum' $\mathrm{KT}$ and Methylobacterium extorquens AM1 can grow on methylamine. mauD, mauE and mauF mutants of ' $M$. flagellatum' $\mathrm{KT}$ and $M$. extorquens AM1 also appeared somewhat similar. These mutants of ' $M$. flagellatum' KT produce considerably decreased amounts of the small subunit polypeptide compared to the wild-type whereas mauD, mauE and mauF mutants of $M$. extorquens AM1 produce amounts of the small subunit polypeptide which are decreased to undetectable levels. However, two ' $M$. flagellatum' $K \mathrm{KT}$ mutants were isolated that were not complemented by the DNA fragments that cover the entire mau gene cluster, and these mutants had pleiotropic phenotypes. Since the Mau system is positively regulated by the presence of amines and is negatively regulated by methanol, it is possible that these mutants are defective in a regulatory function that is not encoded by known mau genes. A positive LysR-type regulator of mau genes in $P$. denitrificans has been described recently by Van Spanning et al. (1995) and its gene was called mauR. Properties of 'M. flagellatum' KT-2.9 and KT2.18 appear to be similar to the mauR mutant described by Van Spanning et al. (1995). Further work will be necessary to assess the role of the gene or genes defective in these mutants. It is also important that the mauM gene product was shown to be required for MADH activity, since other mauM mutants, isolated in $M$. extorquens AM1 and $P$. denitrificans, had normal MADH activity (Chistoserdov et al., 1994a; Van der Palen et al., 1995). It is possible that this function is redundant in $M$. extorquens AM1, $P$. denitrificans but present in only one form in ' $M$. flagellatum' KT.

Another important difference was also found in properties of $m a u G$ mutants of Methylobacterium extorquens AM1, P. denitrificans and 'Metbylobacillus flagellatum'. MauG is a putative $c$-haem-containing peroxidase believed to be involved in TTQ biosynthesis (Lidstrom \& Chistoserdov, 1993). Earlier data of Page $\&$ Ferguson (1993) unambiguously proved that mutants of $M$. extorquens and $P$. denitrificans deficient in $c$-type cytochrome biogenesis synthesize the methylamine dehydrogenase polypeptides but cannot assemble TTQ. A mau $G$ mutant of $P$. denitrificans was not able to synthesize a quinone moiety (Van der Palen et al., 1995). A $m a n G$ mutant of $M$. extorquens AM1 was able to synthesize a quinone moiety in MADH (Chistoserdov et al., 1994a) albeit in only about $10 \%$ of all MADH molecules, and the enzyme has a low residual $\mathrm{MADH}$ activity (G. N. Marchenko \& A. Y. Chistoserdov, unpublished). mau $G$ mutants of ' $M$. flagellatum' were also able to synthesize a quinone moiety in $\mathrm{MADH}$, although it was difficult to estimate quantitatively the intensities of quinone staining in wild-type and mauG strains. The possible explanation of the observed discrepancies could be that in ' $M$. flagellatum' KT and M. extorquens AM1, but not in $P$. denitrificans, an isoenzyme exists which is able to carry out the function of MauG but much less efficiently.

The ability of mau mutants of ' $M$. flagellatum' $\mathrm{KT}$ to utilize amines as sources of nitrogen indicates that $\mathrm{MADH}$ is not the only amine-oxidizing system in this bacterium. Particularly interesting is that ' $M$. flagellatum' KT has a system which allows it to use dimethylamine as a source of nitrogen but not as a source of carbon. Two enzymes are known that are able to oxidize dimethylamine: dimethylamine monooxygenase (Burton et al., 1983) and dimethylamine dehydrogenase (Meiberg \& Harder, 1979). Both enzymes produce methylamine as a product of dimethylamine oxidation. Methylamine would allow 'M. flagellatum' KT to grow on dimethylamine if it had either of these two enzymes. Apparently, ' $M$. flagellatum' KT has a novel dimethylamine oxidation system, which oxidizes dimethylamine directly to ammonia without conservation of energy. 


\section{ACKNOWLEDGEMENTS}

This work was supported in part by grant GM52316 from the $\mathrm{NIH}$ to A.Y.C.

\section{REFERENCES}

Anthony, C. \& Jones, C. W. (1987). Energy metabolism of aerobic, methylotrophic bacteria. In Microbial Growth on $C_{1}$ Compounds, pp. 195-202. Edited by H. W. Van Verseveld \& J. A. Duine. Groningen: University of Groningen.

Auton, K. A. \& Anthony, C. (1989). The role of cytochromes and blue copper proteins in growth of an obligate methylotroph on methanol and methylamine. J Gen Microbiol 135, 1923-1931.

Burton, S. M., Byrom, D., Carver, M., Jones, G. D. D. \& Jones, C. W. (1983). The oxidation of methylated a mines by methylotrophic bacterium Methylophilus methylotrophus. FEMS Microbiol Lett 17, 185-190.

Chandrasekar, R. \& Klapper, M. H. (1986). Methylamine dehydrogenase and cytochrome $c_{552}$ from the bacterium W3A1.J Biol Chem 261, 3616-3619.

Chistoserdov, A. Y., Tsygankov, Y. D. \& Lidstrom, M. E. (1990). Cloning and sequencing of the structural gene for the small subunit of methylamine dehydrogenase from Methylobacterium extorquens AM1: evidence for two tryptophan residues involved in the active center. Biochem Biophys Res Comm 172, 211-216.

Chistoserdov, A. Y., Boyd, J., Mathews, F. S. \& Lidstrom, M. E. (1992). The genetic organization of the mau gene cluster of the facultative autotroph Paracoccus denitrificans. Biochem Biophys Res Commun 184, 1226-1234.

Chistoserdov, A. Y., Chistoserdova, L. V., McIntire, W. S. \& Lidstrom, M. E. (1994a). The genetic organization of the mau gene cluster in Methylobacterium extorquens AM1: complete nucleotide sequence and generation and characteristics of mau mutants. J Bacteriol 176, 4052-4065.

Chistoserdov, A. Y., McIntire, W. S., Mathews, F. S. \& Lidstrom, M. E. (1994b). Organization of the methylamine utilization (mau) genes in Methylophilus methylotrophus W3A1-NS. J Bacteriol 176, 4073-4080.

Dinarieva, T. \& Netrusov, A. (1989). Cupredoxins of obligate methylotroph. FEBS Lett 259, 47-49.

Ditt, G., Schmidhauser, T., Yakobson, E., Lu, P., Liang, X. W., Finlay, D. R., Guiney, D. \& Helinski, D. R. (1985). Plasmids related to the broad host range vector, pRK290, useful for gene cloning and for monitoring gene expression. Plasmid 13, 149-153.

Eady, R. R. \& Large, P. J. (1968). Purification and properties of an amine dehydrogenase from Pseudomonas AM1 and its role in growth on methylamine. Biochem J 106, 245-255.

Fulton, G. L., Nunn, D. N. \& Lidstrom, M. E. (1984). Molecular cloning of a malyl coenzyme A lyase gene from Pseudomonas sp. strain AM1, a facultative methylotroph. J Bacteriol 160, 718-723.

Gak, E. R., Chistoserdov, A. Y. \& Lidstrom, M. E. (1995). Cloning, sequencing, and mutation of a gene for azurin in 'Methylobacillus flagellatum' KT. J Bacteriol 177, 4575-4578.

Govorukhina, N. I., Kletsova, L. V., Tsygankov, Yu. D., Trotsenko, Yu. A. \& Netrusov, A. I. (1987). Characteristics of a new obligate methylotroph. Mikrobiologiya 56, 673-677 (in Russian).

Haywood, G. W., Janschke, N. S., Large, P. J. \& Wallis, J. M. (1982). Properties and subunit structure of methylamine dehydrogenase from Thiobacillus A2 and Methylophilus methylotrophus. FEMS Microbiol Lett 15, 79-82.

Huitema, F., Van Beeumen, J., Van Driessche, G., Duine, J. A. \& Canters, G. W. (1993). Cloning and sequencing of the gene coding for the large subunit of methylamine dehydrogenase from Thiobacillus versutus. J Bacteriol 175, 6254-6259.

Husain, M. \& Davidson, V. L. (1985). An inducible periplasmic blue copper protein from Paracoccus denitrificans: purification, properties, and physiological role. J Biol Chem 260, 14626-14629.

Husain, M. \& Davidson, V. L. (1987). Purification and properties of methylamine dehydrogenase from Paracoccus denitrificans. J Bacteriol 169, 1712-1717.

Janvier, M., Frehel, C., Grimont, F. \& Gasser, F. (1985). Methylophaga marina gen. nov., sp. nov. and Methylophaga thalassica sp. nov., marine methylotrophs. Int J Syst Bacteriol 35, 131-139.

Kenny, W. C. \& Mclntire, W. (1983). Characterization of methylamine dehydrogenase from bacterium W3A1: interaction with reductant and amino-containing compounds. Biochemistry 22, $3858-3868$

Kiriukhin, M. Y., Chistoserdov, A. Y. \& Tsygankov, Y. D. (1990), Methylamine dehydrogenase from 'Methylobacillus flagellatum'. Methods Enzymol 188, 247-256.

Kletsova, L. V., Chibisova, E. S. \& Tsygankov, Y. D. (1988). Mutants of obligate methylotroph 'Methylobacillus flagellatum' KT defective in genes of the ribulose monophosphate cycle of formaldehyde fixation. Arch Microbiol 149, 441-449.

Laemmli, U. K. (1970). Cleavage of structural proteins during the assembly of the head of bacteriophage T4. Nature 227, 680-685.

Lawton, S. A. \& Anthony, C. (1985). The role of copper proteins in the oxidation of methylamine by an obligate methylotroph. Biochem J 228, 719-725.

Lidstrom, M. E. \& Chistoserdov, A. Y. (1993). Molecular biology and genetics of methylamine dehydrogenase. In Microbial Growth on $\mathrm{C}_{1}$ Compounds, pp. 381-400. Edited by J. C. Murrell \& D. P. Kelly. Andover: Intercept.

Maniatis, T., Fritsch, E. T. \& Sambrook, J. (1982). Molecular Cloning: a Laboratory Manual. Cold Spring Harbor, NY: Cold Spring Harbor Laboratory.

Marmur, J. (1961). A procedure for the isolation of deoxyribonucleic acid from microorganisms. J $\mathrm{Mol} B i o l ~ 3$, 208-218.

Matsumoto, T., Shirai, S., Ishii, Y. \& Tobari, J. (1980). Methylamine dehydrogenase of Methylomonas J and Pseudomonas AM1. Hybridization of light and heavy subunits and some properties of an isolated hybrid enzymes. J Biochem 88, 1097-1102.

McIntire, W. S., Wemmer, D. E., Chistoserdov, A. Y. \& Lidstrom, M. E. (1991). A new cofactor in a prokaryotic enzyme: tryptophan tryptophylquinone as the redox prosthetic group in methylamine dehydrogenase. Science 252, 817-824.

Meiberg, J. B. \& Harder, W. (1979). Dimethylamine dehydrogenase from Hyphomicrobium X: purification and some properties of a new enzyme that oxidizes secondary amines. $J$ Gen Microbiol 115, 49-58.

Meinkoth, J. \& Wahl, G. (1984). Hybridization of nucleic acids immobilized on a solid support. Anal Biochem 138, 267-284.

Miller, J. H. (1972). Experiments in Molecular Genetics. Cold Spring Harbor, NY: Cold Spring Harbor Laboratory.

Page, M. D. \& Ferguson, S. J. (1993). Mutants of Methylobacterium extorquens and Paracoccus denitrificans deficient in $c$-type cytochrome biogenesis synthesize the methylamine-dehydrogenase polypeptides but cannot assemble the tryptophan-tryptophanylquinone group. Eur J Biochem 218, 711-718.

Paz, M. A., Fluckiger, R., Boak, A., Kagan, H. M. \& Gallop, P. M. 
(1991). Specific detection of quinoproteins by redox-cycling staining. J Biol Chem 266, 689-692.

Ruvkun, G. B. \& Ausubel, J. R. (1981). A general method for sitedirected mutagenesis in prokaryotes. Nature 289, 85-88.

Simon, R., Priefer, U. \& Puhler, A. (1983). A broad-host-range mobilization system for in vivo genetic engineering: transposon mutagenesis in Gram-negative bcteria. Bio/Technology 1, 784-791.

Tobari, J. (1984). Blue copper proteins in electron transport in methylotrophic bacteria. In Microbial Growth on $C_{1}$ Compounds, pp. 106-112. Edited by R. L. Crawford \& R.S. Hanson. Washington, DC: American Society for Microbiology.

Tobari, J. \& Harada, Y. (1981). Amicyanin : an electron acceptor of methylamine dehydrogenase. Biochem Biophys Res Commun 101, 502-508.

Ubbink, M., van Kleef, M. A. G., Kleinjan, D.-J., Hoitink, C. W. G., Huitema, F., Beintema, J. J., Duine, J. A. \& Canters, G. W. (1991). Cloning, sequencing and expression studies of the genes encoding amicyanin and the $\beta$-subunit of methylamine dehydrogenase from Thiobacillus versutus. Eur J Biochem 202, 1003-1012.

Van der Palen, C. J. N. M., Slotboom, D. J., Jongejan, L., Reijnders, W. N. M., Harms, N., Duine, J. A. \& Van Spanning, R. J.

M. (1995). Mutational analysis of mau genes involved in methylamine metabolism in Paracoccus denitrificans. Eur J Biochem 230, 860-871.

Van Houwelingen, T., Canters, G. W., Stobbelaar, G., Duine, J. A., Frank, J., Jzn. \& Tsugita, A. (1985). Isolation and characterization of a blue copper protein from Thiobacillus versutus. Eur J Biochem 153, 75-80.

Van Spanning, R. J. M., Wansell, C. W., Reijnders, W. N. M., Oltmann, L. F. \& Stouthamer, A. H. (1990). Mutagenesis of the gene encoding amicyanin of Paracoccus denitrificans and the resultant effect on methylamine oxidation. FEBS Lett 275, 217-220.

Van Spanning, R. J. M., van der Palen, C. J. N. M., Slotbook, D.-J., Reijnders, W. N. M., Stouthamer, A. H. \& Duine, J. A. (1995). Expression of the mau genes involved in methylamine metabolism in Paracoccus denitrificans is under control of a LysR-type transcriptional activator. Eur J Biochem 226, 201-210.

Whitaker, J. R. \& Granum, P. E. (1980). An absolute method for protein determination based on difference in absorbance at 235 and $280 \mathrm{~nm}$. Anal Biochem 109, 156-159.

Received 31 October 1996; revised 2 January 1997; accepted 6 January 1997. 